\title{
STRATEGI PEMURIDAN MAHASISWA SEKOLAH TINGGI TEOLOGI ERA NEW NORMAL PANDEMI COVID-19
}

\author{
Oleh: \\ Kezia Yemima \\ Dosen Sekolah Tinggi Teologi Gamaliel \\ Email: kezia_y@hotmail.com
}

\begin{abstract}
ABSTRAK - Pandemi Covid-19 berdampak pada Sekolah Tinggi Teologi (STT). Kegiatan pendidikan, persekutuan maupun kegiatan yang melibatkan banyak mahasiswa dan menimbulkan kerumunan harus dibatasi. Tujuan dari penelitian ini adalah untuk merumuskan strategi pemuridan bagi mahasiswa di sekolah tinggi teologi yang tepat, alkitabiah, dan kontekstual pada era New Normal pandemi Covid-19. Penelitian ini menggunakan metode penelitian teologia sistematika kualitatif yaitu metode induktif. Strategi pemuridan mahasiswa teologi yang dihasilkan, yaitu: pertama, para dosen perlu hadir dalam kehidupan mahasiswa yang dilayani menggunakan berbagai media Teknologi Informasi dan Komputer(TIK) dan menyampaikan Kabar Baik dengan sederhana, jelas, sikap yang benar, terbuka, dan gigih menggunakan setiap kesempatan untuk memberitakan kabar baik sampai dapat diterima. Kedua, dosen menggabungkan para mahasiswa yang dilayani dalam Kelompok Tumbuh Bersama Kontekstual (KTBK) yang memiliki kegiatan secara online dan offline. Ketiga, dosen memperlengkapi para mahasiswa melalui pelatihan-pelatihan pelayanan yang dilakukan dengan bantuan TIK. Keempat, pelayan mengutus para mahasiswa untuk bermultiplikasi dengan melakukan hal yang sama melalui pengurapan Roh Kudus.
\end{abstract}

Kata Kunci: Strategi Pemuridan, Dosen dan Mahasiswa Teologi, Era New Normal Pandemi Covid-19, Sekolah Tinggi Teologi, KTBK

\begin{abstract}
Covid-19 Pandemic has an impact on theological colleges. Teaching activities, Fellowship activities and activities that involve many student dan cause crowds must be limited. The purpose of this studied was to formulate appropriate, biblical, and contextual discipleship strategies in theological colleges during the New Normal Covid-19 pandemic era. This studied used qualitative systematic theological research methods, namely the inductive method. The resulting discipleship strategies are: first, the lecturer need to be present in the lives of students who are served using various ICT media and deliver the good news with a simple, clear, right attitude, open and persistent use every opportunity to preach the good news until it can be accepted. Second, the lecturer combine students who are served in the Contextual Bible Group who have online and offline activities. Third, the lecturer equip students through service training conducted with the help of ICT. Fourth, the Lecturer sent students to multiply by doing the same thing through the anointing of the Holy Spirit.
\end{abstract}

Keywords: Discipleship Strategy, Lecturer dan New Normal Covid-19 Pandemic Era, Theological Colleges, $C B G$ 


\section{PENDAHULUAN}

Pandemi Coronavirus disease 2019 (Covid-19) sedang melanda seluruh dunia. Virus ini pertama kali muncul pada Desember 2019 di Kota Wuhan, Provinsi Hubei, China ${ }^{1}$ dan telah menjalar ke seluruh dunia termasuk Indonesia. Kasus pertama Covid-19 di Indonesia terjadi pada 2 Maret 2020 dengan ditemukan 2 kasus positif. $^{2}$ Organisasi Kesehatan Dunia (WHO) menetapkan virus ini sebagai pandemi pada 11 Maret 2020. ${ }^{3}$ Pandemi adalah wabah yang berjangkit serempak meliputi daerah geografis yang luas. ${ }^{4}$

Tren kasus Covid-19 di Indonesia saat ini masih terus mengalami peningkatan. Per tanggal 1 September 2020, terdapat 177.571 kasus terkonfirmasi, 80.675 suspek Covid-19, 7.505 pasien meninggal dunia, dan 128.057 pasien sembuh. ${ }^{5}$ Bahkan 100 dokter telah

\footnotetext{
${ }^{1}$ World Health Organization, "Q\&A on Coronaviruses (COVID-19)," Who, 2020.

${ }^{2}$ Kementerian kesehatan Republik Indonesia, "Pedoman Pencegahan Dan Pengendalian COVID-19," Pedoman kesiapan menghadapi COVID-19 (2020): 0-115.

${ }^{3}$ Nailul Mona, "Konsep Isolasi Dalam Jaringan Sosial Untuk Meminimalisasi Efek Contagious ( Kasus Penyebaran Virus Corona Di Indonesia)," Jurnal Sosial Humaniora Terapan 2, no. 2 (2020): 117-125.

${ }^{4}$ Badan Pengembangan dan Pembinaan Bahasa Kemendikbud RI, "Hasil Pencarian - KBBI Daring," Badan Pengembangan Dan Pembinaan Bahasa, Kementerian Pendidikan Dan Kebudayaan Republik Indonesia, 2020.

${ }^{5}$ Irfan Kamil, "UPDATE 1 September: Kasus Suspek Covid-19 Tembus 80.675 Orang," Kompas.Com, last modified 2020, accessed September 2, 2020, https://nasional.kompas.com/read/2020/09/01/1528 2601/update-1-september-kasus-suspek-covid-19tembus-80675-orang.
}

meninggal akibat Covid-19. ${ }^{6}$ Kenaikan tren kasus Covid-19 tersebut menjadi keprihatinan bagi seluruh masyarakat Indonesia, karena berdampak terhadap seluruh bidang di Indonesia, termasuk bidang pendidikan teologi.

Bidang pendidikan teologi yang terdampak pandemi Covid-19 salah satunya adalah pendidikan tinggi teologi. Dampak Covid-19, membuat seluruh aktivitas di kampus teologi menjadi terganggu. Sejak diterbitkan Surat Edaran Menteri Pendidikan dan Kebudayaan Republik Indonesia No. 4 Tahun 2020 tentang pelaksanaan kebijakan pendidikan dalam masa darurat penyebaran Covid-19, maka semua aktivitas perkuliahan dilakukan dari rumah atau disebut Belajar dari Rumah menggunakan pembelajaran online. $^{7}$

Belajar dari Rumah bagi Sekolah Tinggi Teologi berdampak pada aktivitas pembelajaran. Dampak tersebut di antaranya: penggunaan jaringan membutuhkan infrastruktur yang memadai, membutuhkan banyak biaya, dan berbagai kendala komunikasi melalui internet. ${ }^{8}$ Selain itu, Belajar dari Rumah menjadikan komunikasi antara dosen dan mahasiswa tidak dapat dilakukan secara face to face

\footnotetext{
${ }^{6}$ Retia Kartika Dewi, “100 Dokter Meninggal Karena Covid-19, Apa Penyebabnya?,"

Kompas.Com, last modified 2020, accessed September 2, 2020,

https://www.kompas.com/tren/read/2020/08/31/191 500565/100-dokter-meninggal-karena-covid-19apa-penyebabnya-?page=all.

${ }^{7}$ Mendikbud, "SE Menteri Nomor 4 Tahun 2020” (Jakarta: Kemendikbud, 2020).

${ }^{8}$ E W Pratiwi, "Dampak Covid-19 Terhadap Kegiatan Pembelajaran Online Di Sebuah Perguruan Tinggi Kristen Di Indonesia," Perspektif Ilmu Pendidikan 34, no. 1 (2020): 1-8.
} 
(F2F) sehingga kegiatan seperti pemuridan mahasiswa mengalami kesulitan. Dampak lainnya yaitu seluruh aktivitas mahasiswa yang menimbulkan kerumunan orang banyak harus dihentikan.

Dampak pandemi Covid-19 sangat menganggu pendidikan di Sekolah Tinggi Teologi karena pendidikan di Sekolah Tinggi berbeda dengan pendidikan nonteologi. Hampir seluruh STT tidak bisa mewajibkan mahasiswa tinggal di asrama, ibadah wajib, mission trip bagi mahasiswanya. Padahal kegiatan-kegiatan ini penting untuk memaksimalkan pengetahuan mahasiswa akan kebenaran firman Tuhan.

Pemuridan dalam kelompok kecil seharusnya menjadi solusi bagi permasalahan ini. Pemuridan kelompok kecil tidak membuat kerumunan banyak orang. Pemuridan kelompok kecil juga flexible dalam bentuk kegiatan (online, offline). Namun, menurut pengamatan peneliti sebagai dosen teologi, STT sekolah tinggi teologi belum menerapkan pemuridan yang terstruktur bagi mahasiswanya. Sekolah tinggi teologi hanya memfokuskan kepada pembelajaran dan praktek pelayanan.

Penelitian-penelitian di Perguruan Tinggi (PT) umum menyimpulkan bahwa pemuridan penting bagi mahasiswa. Panuntun dan paramita mengatakan bahwa pemuridan dapat meningkatkan pemahaman nilai-nilai kebangsaan. ${ }^{9}$ Sarumaha dan Pasuhuk mengatakan pemuridan merupakan salah satu strategi untuk membangun karakter peduli

\footnotetext{
${ }^{9}$ Daniel Fajar Panuntun and Eunike Paramita, "Hubungan Pembelajaran Alkitab Terhadap NilaiNilai ( Kelompok Tumbuh Bersama Kontekstual )," Gamaliel : Teologi praktika 1, no. 2 (2019): 113.
}

mahasiswa. ${ }^{10}$ Purba mengatakan bahwa pemuridan seharusnya menjadi tugas dosen bahkan dosen Pendidikan Agama Kristen di perguruan tinggi umum. ${ }^{11}$

Berdasarkan pertimbangan tersebut, artikel ini berusaha memberikan solusi bagi Sekolah Tinggi Teologi dengan menyusun sebuah strategi pemuridan pada era New Normal pandemi Covid-19 yang alkitabiah dan kontekstual.

\section{RUMUSAN MASALAH}

Rumusan masalah dalam tulisan ini adalah, bagaimana strategi pemuridan yang tepat, alkitabiah, dan kontekstual bagi mahasiswa sekolah tinggi teologi pada masa pandemi Covid-19?

Artikel ini bertujuan untuk merumuskan sebuah strategi pemuridan mahasiswa di Sekolah Tinggi Teologi yang kontekstual era New Normal pandemi Covid-19.

Artikel ini memberikan dua manfaat, yaitu: Pertama, secara teoritis menambah kekayaan teologi praktika dalam bidang pendidikan dan pemuridan di Sekolah Tinggi Teologi pada masa pandemi. Kedua, secara praktis dapat meningkatkan kompetensi mahasiswa dalam pelayanan pemuridan dan transformasi kepribadiaan agar menjadi dewasa rohani serupa Yesus baik dalam kognitif, karakter, perilaku di era New Normal pandemi Covid-19. Demikian pula bagi Sekolah Tinggi Teologi dapat memperoleh strategi yang tepat untuk

\footnotetext{
${ }^{10}$ Nurnilam Sarumaha and Novie Deisy Pasuhuk, "Strategi Membangun Karakter Peduli Sesama Di Kalangan Mahasiswa Teologi Berdasarkan Filipi 2 : 1-8," Teruna Bhakti 2, no. 2 (2020): 143.

${ }^{11}$ Asmat Purba, "Pemuridan Sebagai Tugas Dosen Pendidikan Agama Kristen Di Perguruan Tinggi," TEDC 8, no. 1 (2014): 68-73.
} 
meningkatkan pendidikan teologi yang aplikatif.

\section{METODE PENELITIAN}

Artikel ini menggunakan metode penelitian teologia sistematika kualitatif yaitu metode induktif. Metode induktif adalah studi metodologis dengan pendekatan kualitatif berdasarkan penalaran induktif dan paradigma fenomenologi yang menghasilkan materi teologia yang bersifat mendasar, komprehensif, dan berintegrasi, yang belum dilakukan penelitian lapangan. ${ }^{12}$

Langkah-langkah dalam penelitian ini mengikuti langkah-langkah metode induktif yang telah disesuaikan, sebagai berikut: ${ }^{13}$ Pertama, mengidentifikasi dan menganalisis secara eksegetis bagianbagian Alkitab yang berhubungan dengan topik yang diteliti. Kedua, mengkaji materi biblikal tersebut dengan pendapat para ahli yang telah mengkaji di masa sebelumnya dan penerangan dari sumber-sumber lain (sekuler). Ketiga, menyusun sebuah strategi pendidikan di Sekolah Tinggi Teologi pada era New Normal pandemi Covid-19 dengan mengekspresikan secara kekinian mengenai kebenaran-kebenaran Alkitab dengan kenyataan hidup yang sedang berlangsung.

Teknik pengumpulan data menggunakan teknik dokumentasi yaitu pengambilan data yang diperoleh melalui

\footnotetext{
${ }^{12}$ Stevri Indra Lumintang and Danik Astuti Lumintang, Theologia Penelitian Dan Penelitian Theologis (Geneva Insani Indonesia, 2016).

${ }^{13}$ Ibid.
}

dokumen-dokumen. ${ }^{14}$ Data diambil dari berbagai sumber dokumen di antaranya: Alkitab, buku-buku, jurnal penelitian, dan website-website terpercaya.

\section{HASIL DAN PEMBAHASAN}

\section{Strategi Pemuridan Yesus}

Para tokoh pemuridan menjelaskan arti pemuridan dengan berbagai definisi. Jika ditinjau dari arti kata pemuridan (disciple-making) yang berasal dari kata kerja Yunani matheteusate ( $\mu \alpha \tau \eta \varepsilon \tau \varepsilon v \sigma \alpha \tau \varepsilon)$ adalah membuat murid atau menjadikan murid. ${ }^{15}$ Bill berpendapat bahwa pemuridan adalah percaya pada apa yang Yesus percayai (transformasi pikiran), hidup seperti Yesus hidup (transformasi karakter), mengasihi seperti Yesus mengasihi (transformasi hubungan), melayani seperti Yesus melayani (transformasi pelayanan), dan memimpin seperti Yesus memimpin (transformasi kuasa pengaruh). ${ }^{16}$ Dempsey menyatakan bahwa pemuridan adalah proses seorang murid bertumbuh ke arah kedewasaan rohani, menemukan dan menggunakan karunia, talenta, kemampuannya dalam melaksanakan misi pelayanan Yesus. ${ }^{17}$

Injil Sinoptik dan Injil Yohanes mencatat peristiwa Yesus bersama

\footnotetext{
${ }^{14}$ Wagiran, Metodologi Penelitian Pendidikan: Teori Dan Implementasi, 1st ed. (Yogyakarta: Deepublish, 2015).

15 BIll Hull, Panduan Lengkap Pemuridan (Yogyakarta: Yayasan Gloria, 2014), 28.

${ }^{16}$ BIll Hull, Choose The Life (Surabaya: Literatur Perkantas Jawa Timur, 2004), 18-20.

${ }^{17}$ Rod Dempsey, "What Is God's Will for My Life? Disciple!," in Innovate Church (Nashville: B \& H Academic, 2008), 87.
} 
murid-murid secara lengkap. Injil Sinoptik menunjukkan bahwa tujuan pemuridan yang dilakukan Yesus kepada para murid-Nya adalah mengamanatkan mereka untuk menjadikan semua bangsa murid Yesus dan mendidik dalam ajaran Yesus (Matius 28:16-20). Sedangkan dalan Injil Yohanes, tujuan pemuridan yang dilakukan Yesus adalah mendelegasikan kepemimpinan gembala kepada Petrus dan kawan-kawannya serta diutus untuk mengemban misi pelayanan-Nya. Michael Shipman menegaskan bahwa Yesus datang ke dunia untuk melakukan misi-Nya, namun pekerjaan-Nya belum selesai sampai para murid diutus untuk memuridkan orang lain. Yesus mengatakan sama seperti Bapa telah mengutus Aku ke dalam dunia, demikian pula Aku telah mengutus para murid ke dalam dunia (Yoh 17:18). ${ }^{18}$ Jadi, para murid diutus Yesus ke daerah baru yang lebih luas untuk menjangkau, memuridkan, dan menggembalakan.

Alkitab menunjukkan keberhasilan Yesus dalam mencapai tujuan pemuridan tersebut. Karena itu, orang percaya patut meneladani strategi Yesus dalam memuridkan. Maka fokus penelitian ini adalah melihat bagaimana strategi Yesus melakukan pemuridan kepada kedua-belas murid-Nya.

Strategi pemuridan banyak diteladankan di Alkitab. Contoh strategi pemuridan yang patut diteladani adalah strategi pemuridan Yesus. Fokus penelitian ini adalah melihat bagaimana Yesus

\footnotetext{
${ }^{18}$ Michael Shipman, Amanat Agung Asli Rahasia Memuridkan Dunia Kini (Rahayu Group, 2014), 38.
}

melakukan pemuridan kepada keduabelas murid-Nya.

Yesus memuridkan keduabelas murid-Nya dalam kehidupan keseharian selama tiga setengah tahun. Selama itu, Yesus berelasi dengan murid-murid siang dan malam. Sehingga Yesus dapat melakukan proses pemuridan kepada murid-murid-Nya tiap saat.

Yesus memuridkan para murid melalui tiga proses. ${ }^{19}$ Proses pertama, Yesus melibatkan para murid dalam pelayanan yang dikerjakan. Yesus dan para murid sering terlibat dalam pelayanan bersama. Para murid selalu menyertai Yesus sehingga proses ini dapat terjadi. Salah satu contohnya adalah ketika peristiwa Yesus memberi makan 5000 orang, para murid dilibatkan untuk membagikan roti dan ikan.

Proses kedua, Yesus mengajak para murid untuk terlibat dalam disiplin rohaninya. Para murid setiap hari bersama Yesus tentu mereka melihat dan mengerti kebiasaan yang Yesus lakukan. Pada kesempatan khusus Yesus juga mengajak murid-Nya untuk terlibat dalam kegiatan rutin kerohanian-Nya. Salah satu contohnya ketika di taman Getsemani, Yesus mengajak Petrus, Yakobus, dan Yohanes untuk menemani Yesus berdoa.

Proses ketiga, Yesus menyampaikan firman Tuhan secara interaktif. Yesus juga mengajarkan firman Tuhan kepada para murid-Nya. Yesus sering menjelaskan apa arti hukum Taurat

\footnotetext{
${ }^{19}$ Timotius Haryono and Daniel Fajar Panuntun, “ANDIL PEMURIDAN KONTEKSTUAL YESUS KEPADA PETRUS YAKOBUS DAN YOHANES TERHADAP KETERBUKAAN KONSELING MAHASISWA PADA MASA KINI," Jurnal Gamaliel : Teologi Praktika (2019): 16-18.
} 
maupun pengajaran Yesus. Yesus juga memberikan waktu bagi para murid untuk berdiskusi menanyakan hal-hal yang belum dimengerti.

Pemuridan yang digunakan Yesus merupakan strategi yang tidak lekang oleh waktu dan merupakan strategi terbaik. Model pemuridan Yesus mencakup semua aspek dalam keempat kategori utama (edukasional, atraksional, missional, dan organik) tetapi memiliki sesuatu yang berbeda sebagai penggerak fokus. ${ }^{20}$

Yesus memiliki strategi untuk mendekatkan orang kepada Allah. Fokus utamanya adalah berinvestasi pada sekelompok kecil orang sehingga mereka, pada gilirannya, akan tumbuh menuju kedewasaan rohani dan membuat lebih banyak murid. ${ }^{21}$ Yesus berbagi dengan orang-orang tentang siapa dia melalui katakata dan perbuatan. Ketika orang-orang menerima pesannya, Ia mengundang mereka untuk berhubungan dengan-Nya dalam suatu hubungan. Selama waktu berbagi kehidupan bersama, Dia mengajar mereka mengenai kebenaran tentang Allah. Seraya murid-murid ini tumbuh, Yesus melatih mereka untuk melayani yang terhilang dan kepada pengikut-pengikut lainnya. Akhirnya, setelah Ia bangkit dari kematian, ia mengerahkan pengikutnya untuk memuridkan orang lain.

Yesus menggunakan empat tahap pemuridan yang disebut $\mathrm{SCMD}^{22}$, yaitu: Share. Pembuat murid menginkarnasikan

\footnotetext{
${ }^{20} \mathrm{Jim}$ Putman, Bobby Harrington, and Robert E Coleman, DiscipleShift: Five Steps That Help Your Church to Make Disciples Who Make Disciples, Exponential Series (California: Zondervan, 2013).

${ }^{21}$ Ibid.

${ }^{22}$ Ibid.
}

kehidupan Kristus di dalam sebuah dunia yang hilang dan kemudian mengundang orang untuk menanggapi Kristus. Inkarnasi berarti bahwa, seperti Yesus, pembuat murid masuk ke dunia yang hilang sebagai pelayan. Undangan berarti bahwa sama seperti Yesus, pembuat murid harus mengundang orang untuk menanggapi Dia. Skala Engel adalah model populer yang dapat digunakan untuk membantu orang lebih memahami gagasan bahwa konversi adalah suatu proses, bukan peristiwa satu kali. Sebagaimana ditunjukkan oleh gambar 2, pertobatan kepada Kristus bukanlah saat pertama dalam proses.

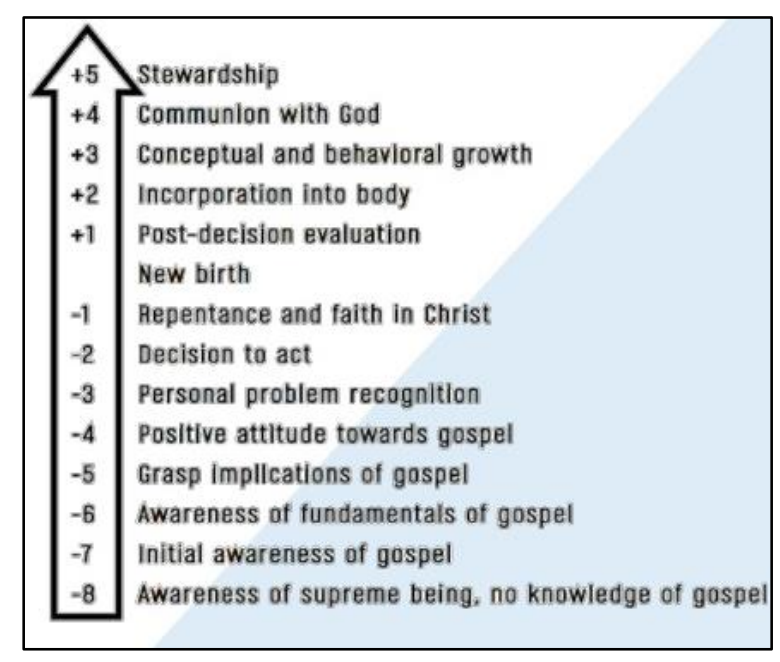

Gambar 2. Skala Engel

(Sumber: Jim Putman, Bobby Harrington, dan Robert E Coleman, DiscipleShift: Five

Steps That Help Your Church to Make

Disciples Who Make Disciples, Exponential Series, 2013)

Connect. Orang Kristen baru ditolong untuk bergaul dengan muridmurid lain dan menguduskan diri mereka kepada Allah. Alkitab tidak menggambarkan orang Kristen yang sendirian atau terisolasi. Mengikuti Yesus adalah sesuatu yang dapat dilakukan secara efektif hanya 
jika terhubung dengan murid-murid lain dalam sebuah komunitas. Asosiasi berarti bahwa seperti Yesus, pembuat murid membangun hubungan relasional yang berkelanjutan dengan mereka yang meresponsnya. Pengudusan berarti bahwa seperti Yesus, pembuat murid membantu orang untuk menaati ajaran Allah.

Train to Minister. Pada tahap ini, para pembuat murid mendorong para murid untuk menunjukkan layanan kepada orang lain, mendelegasikan peluang layanan, dan mengawasi kemajuan. Peragaan berarti bahwa Yesus menunjukkan kepada murid-murid-Nya cara melayani. Delegasi berarti bahwa Yesus memberi murid-murid-Nya sesuatu untuk dilakukan. Pengawasan berarti bahwa Yesus membuat para murid-Nya bertanggung jawab.

Release to Be a Disciple Maker. Pada tahap akhir, para pembuat murid berharap bahwa para murid yang telah matang belajar untuk mereproduksi muridmurid lain. Impartasi Roh Kudus membimbing kehidupan mereka. Reproduksi berarti bahwa Yesus mengantisipasi keberhasilan. Impartasi berarti bahwa Yesus memberi Roh kepada para pengikutnya.

\section{Pemuridan Kelompok Tumbuh Bersama Kontekstual (KTBK)}

Pemuridan model Kelompok

Tumbuh Bersama Kontekstual (KTBK) merupakan salah satu pelayanan dalam konteks mahasiswa umum (non teologi) yang terbukti berdampak positif terhadap kehidupan mahasiswa. ${ }^{23}$ KTBK memiliki

\footnotetext{
${ }^{23}$ Haryono and Panuntun, "ANDIL PEMURIDAN KONTEKSTUAL YESUS
}

visi supaya setiap anggota pemuridan menjadi serupa dengan Yesus. Visi tersebut diwujudkan dengan melakukan misi, yaitu: pertama, mendorong anggota pemuridan bertumbuh ke arah kedewasaan penuh; kedua, memperlengkapi anggota pemuridan dengan pengetahuan Alkitab kontekstual; ketiga, mengontrol ketaatan para anggota pemuridan terhadap firman Tuhan; keempat, melipatgandakan KTBK. $^{24}$

Misi KTBK dapat terwujud melalui empat unsur penting. ${ }^{25}$ Pertama, unsur pembelajaran (learning). Keserupaan dan kedewasaan penuh di dalam Kristus dapat terwujud dengan belajar firman Tuhan dan kerelaan untuk menaatinya. Belajar firman Tuhan melalui KTBK juga disertai dengan belajar buku-buku rohani, sharing antar anggota, diskusi tentang pengalamanpengalaman rohani, aksi ketaatan seluruh anggota, dan lain sebagainya.

Kedua, unsur penyembahan dan doa (worship). KTBK lekat dengan unsur worship yang membuat anggota pemuridan lebih mengenal Allah. Worship dapat dilakukan dengan doa, puji-pujian, kidung, pembacaan Mazmur, dan lainnya. Doa menjadi wujud kerendahan hati di hadapan Tuhan. Berdoa bersama anggota pemuridan dapat menjadi sarana untuk permohonan pribadi, memohon pimpinan serta berkat Tuhan, dan bersyafaat.

KEPADA PETRUS YAKOBUS DAN YOHANES TERHADAP KETERBUKAAN KONSELING MAHASISWA PADA MASA KINI."

${ }^{24}$ Timotius Haryono and Trifena Yuliati, Pemuridan Kontekstual: Contextual Bible Group (Surakarta: Yayasan Gamaliel, 2018). ${ }^{25}$ Ibid. 
Ketiga, unsur persekutuan (fellowship). Persekutuan menolong para anggota pemuridan memiliki rasa saling mengasihi, menolong, melayani, memperhatikan, membangun, manasihati, dan berbagi. Persekutuan menunjukkan bahwa para anggota pemuridan adalah benarbenar murid Yesus.

Keempat, pengutusan (mission). Pengutusan adalah kesaksian para anggota pemuridan untuk memberitakan kabar baik dan membentuk kelompok baru. Pengutusan memungkinkan para anggota pemuridan untuk mengubah kehidupan pribadi orang lain dan masyarakat.

Pemuridan KTBK membagi dua peran dalam satu kelompok KTBK. Peran pertama adalah pemimpin KTBK. Pemimpin KTBK adalah seseorang yang merencanakan, mengarahkan, mengajar, melatih, mengevaluasi, memberi teladan, dan memelihara kelompok KTBK. Peran kedua adalah anggota KTBK. Anggota KTBK adalah seorang yang belajar dalam anggota KTBK. ${ }^{26}$

Relasi antar anggota dan pemimpin KTBK adalah saling melayani dan bertumbuh bersama ke arah Yesus. ${ }^{27}$ Dengan demikian dalam kelompok KTBK pemimpin tidak menjadi pusat dalam pemuridan. Tetapi baik anggota dan pemimpin bersama-sama belajar kepada Yesus sang Guru yang Agung.

\section{Tentang Covid-19}

Coronavirus adalah keluarga besar dari virus-virus yang mengakibatkan penyakit pada hewan dan manusia. Pada manusia, coronavirus menyebabkan

\footnotetext{
${ }^{26}$ Ibid., 97-103.

${ }^{27}$ Ibid., 97-98.
}

infeksi pada saluran pernafasan mulai dari flu biasa hingga penyakit Middle East Respiratory Syndrome (MERS) dan Severe Acute Respiratory Syndrome (SARS). Coronavirus terbaru yang ditemukan menyebabkan penyakit coronavirus disease (Covid-19). ${ }^{28}$

Covid-19 dapat menular melalui kontak erat dan droplet, namun tidak melalui udara. ${ }^{29}$ Hal tersebut berdampak pada pencegahan penularan virus. Pencegahan dilakukan dengan melakukan social distancing dan physical distancing, yaitu menjaga jarak antarmanusia, menghindari kerumunan, dan menjauhi pertemuan massal. ${ }^{30}$

\section{Dampak Covid-19 bagi Mahasiswa}

Pandemi Covid-19 telah memengaruhi pendidikan di Indonesia. Pada satuan pendidikan dan perguruan tinggi diberlakukan Belajar dari Rumah untuk memutus mata rantai penyebaran Covid-19. Hal ini berdampak pada terbatasnnya pertemuan antarmahasiswa di mana seluruh kegiatan mahasiswa di dalam maupun di luar perkuliahan juga turut dibatasi.

Aktivitas perkuliahan dilakukan dengan menggunakan pembelajaran elektronik (e-learning). E-learning terbukti baik dan efektif untuk digunakan dalam pembelajaran pada masa Covid-19 karena dapat menyelesaikan perkuliahan. ${ }^{31}$

\footnotetext{
${ }^{28}$ Kementerian kesehatan Republik Indonesia, "Pedoman Pencegahan Dan Pengendalian COVID-19."

${ }^{29}$ Ibid.

${ }^{30}$ Pratiwi, "Dampak Covid-19 Terhadap Kegiatan Pembelajaran Online Di Sebuah Perguruan Tinggi Kristen Di Indonesia.” ${ }^{31}$ Ibid.
} 
Kendala umum yang dihadapi dalam penerapan e-learning adalah kendala sinyal di beberapa tempat dan penggunaan kuota yang relatif boros. Kendala lain yang dihadapi dengan penerapan e-learning yaitu: pertama, keterbatasan penguasaan teknologi informasi; kedua, sarana dan prasarana yang kurang memadai; ketiga, keterbatasan akses internet; dan keempat, kurang siapnya penyediaan anggaran. ${ }^{32}$

\section{Strategi Pemuridan Mahasiswa Teologi pada Era New Normal Pandemi Covid- 19}

Strategi merupakan suatu rencana yang cermat tentang suatu kegiatan tertentu untuk mencapai sasaran khusus. ${ }^{33}$ Strategi pemuridan mahasiswa teologi pada era New Normal pandemi Covid-19 dimulai dengan merumuskan tujuan dan sasaran yang akan dicapai dalam pemuridan. Tujuan adalah arah atau haluan pemuridan mahasiswa. ${ }^{34}$ Tujuan dari pemuridan mahasiswa teologi berpusat pada tujuan Yesus, yaitu menyatakan Kerajaan Allah atau pemerintahan Allah. Penyataan Kerajaan Allah yang pertama adalah penyataan Kristus yang membebaskan dari kuasa dosa. ${ }^{35}$ Yesus memiliki tujuan supaya setiap manusia memiliki kehidupan kekal melalui kerelaan-Nya berinkarnasi menjadi

\footnotetext{
${ }^{32}$ Rizqon H Syah, "Dampak Covid-19 Pada Pendidikan Di Indonesia: Sekolah,

Keterampilan, Dan Proses Pembelajaran," SALAM: Jurnal Sosial dan Budaya Syar-i 7 , no. 5 (2020).

${ }^{33}$ Kemendikbud RI, "Hasil Pencarian - KBBI

Daring."

${ }^{34}$ Ibid.

${ }^{35}$ Y Tomatala, Penginjilan Masa Kini 1

(Malang: Gandum Mas, 1998).
}

manusia dan melakukan karya penebusan di atas kayu salib. Yesus memiliki tugas utama yang terlihat dari titik kemenanganNya. Ia menjelma dengan satu tujuan, yaitu mati ganti kita pada kayu salib (Fil. 3: 511). ${ }^{36}$

Penyataan Kerajaan Allah yang kedua adalah penyataan pembebasan Allah yang menekankan kepada kewajiban taat dari mereka yang telah dibebaskan dari dosa. ${ }^{37}$ Berdasarkan kedua penyataan tersebut, maka tujuan pelayanan mahasiswa yang tepat, alkitabiah, dan kontekstual adalah menyatakan Kerajaan Allah kepada semua mahasiswa dengan penyampaian kabar baik dan melakukan pemuridan. Penyampaian Kabar Bbaik bertujuan untuk memberitakan penebusan dosa di dalam Yesus Kristus dan pemuridan bertujuan untuk membentuk para mahasiswa memiliki kedewasaan penuh serta menjadi serupa dengan Kristus melalui ketaatan, yang merupakan ciri khas seorang murid (disciple $=$ disiplin).

Sasaran merupakan sesuatu yang menjadi tujuan. $^{38}$ Sasaran pemuridan mahasiswa teologi pada era New Normal pademi Covid-19 ini adalah mahasiswa teologi yang belum dan sudah menerima Yesus sebagai Tuhan dan Juru Selamat pribadi. Yesus datang ke dunia bagi seluruh umat manusia, di mana mahasiswa menjadi bagian di dalamnya. Bagi mahasiswa teologi yang belum menerima Yesus sebagai Tuhan dan Juru Selamat pribadi, pemuridan berfokus pada tujuan penyampaian kabar baik dan dilanjutkan

\footnotetext{
${ }^{36}$ Stanley Heath, Penginjialn Dan Pelayanan Pribadi (Surabaya: YAKIN, 1979).

${ }^{37}$ Tomatala, Penginjilan Masa Kini 1.

${ }^{38}$ Kemendikbud RI, "Hasil Pencarian - KBBI Daring."
} 
dengan pendewasaan serupa Yesus, sedangkan bagi mahasiswa teologi yang telah menerima Yesus, pelayanan berfokus pada tujuan pemuridan supaya setiap mahasiswa menjadi dewasa penuh dan serupa dengan Yesus.

Setelah tujuan dan sasaran pelayanan mahasiswa dirumuskan maka hal yang perlu dilakukan adalah menentukan pelaksana pemuridan. Pemuridan KTBK di sekolah tinggi teologi adalah dosen. Dosen adalah orang yang bertanggungjawab dalam mendidik dan menjadikan mahasiswa seorang pelayan Kristus. Anggota KTBK dalam pemuridan di sekolah tinggi teologi adalah mahasiswa teologi. Pembagian kelompk dapat berdasarkan pembagian pembimbing akademik.

Menyusun langkah-langkah pemuridan. Pertama, bagi mahasiswa teologi yang belum mengenal Yesus maka para dosen perlu hadir dalam kehidupan mahasiswa yang dilayani dan menyampaikan (Share) tentang kabar baik, seperti yang diringkas dalam 1 Kor. 15: 3-4 berikut:

"Sebab yang sangat penting telah
kusampaikan kepadamu, yaitu apa
yang telah kuterima sendiri, ialah
bahwa Kristus telah mati karena
dosa-dosa kita, sesuai dengan
Kitab Suci, bahwa Ia telah
dikuburkan, dan bahwa Ia telah
dibangkitkan, pada hari yang
ketiga, sesuai dengan Kitab Suci"
(TB)

Penyampaian kabar baik harus berfokus pada ringkasan yang sederhana tersebut. Sedangkan, perkara-perkara di luar Kabar Baik tidak terlalu penting dan perlu dibatasi untuk diberitakan. ${ }^{39}$ Kerelaan pemberita Kabar Baik untuk membatasi diri menyampaikan perkaraperkara di luar ringkasan Kabar Baik justru akan memberikan hasil yang besar bagi penuaian jiwa-jiwa.

Kehadiran pemuridan bagi mahasiswa teologi yang dilayani pada era New Normal pandemi Covid-19 dapat memanfaatkan Teknologi Informasi dan Komunikasi (TIK). Pelayanan pada era New Normal pandemi Covid-19 tidaklah semudah seperti dalam keadaan normal. Pada era New Normal pandemi Covid-19, aktivitas dibatasi dengan adanya physical distancing maupun protokol kesehatan lainnya. Namun demikian, para pelayan dapat memanfaatkan berbagai media sosial dan fasilitas chatting seperti facebook, instagram, twitter, whatsapp, telegram, facebook massanger, direct massage instagram dan sebagainya untuk bertemu dengan para mahasiswa dan menjalin komunikasi untuk memberitakan kabar baik, di mana media sosial terbukti efektif untuk melakukan komunikasi, karena kemudahan untuk diakses dan digunakan. ${ }^{40}$

$$
\text { Pemberitaan Kabar Baik }
$$
menggunakan TIK harus dilakukan dengan sikap yang benar. Para pelayan harus dapat mengendalikan pembicaraan melalui forum maupun chat sehingga timbul pertanyaan-pertanyaan dan rasa ingin tahu dari mahasiswa yang dilayani. Para pelayan tidak boleh menasihati atau menghakimi mahasiswa yang masih duniawi (belum menerima Yesus), karena

\footnotetext{
${ }^{39}$ Heath, Penginjialn Dan Pelayanan Pribadi. ${ }^{40}$ Ahmad Setiadi, "Pemanfaatan Media Sosial Untuk Efektifitas Komunikasi," Jurnal Humaniora 16, no. 2 (2016): 1-7.
} 
mereka tidak akan gemar membicarakan perkara-perkara rohani. ${ }^{41}$ Para pelayan harus bersikap terbuka dan memakai setiap kesempatan untuk memberitakan Kabar Baik, dimulai dengan pertanyaanpertanyaan umum dan berusaha untuk memperoleh pendapat dari mahasiswa yang dilayani mengenai hal yang harus diperbuat supaya seseorang dapat masuk dalam kehidupan kekal.

Pemberitaan tentang Kabar Baik mungkin tidak diterima dalam pemberitaan yang pertama. Skala Engel menyatakan bahwa penyampaian kabar baik merupakan sebuah proses sehingga para dosen tidak boleh putus asa dan harus terus memberitakan Kabar Baik kepada orang yang dilayani. Heath menyampaikan tiga tahapan sebelum seseorang dapat sungguhsungguh menerima kabar baik: ${ }^{42}$ 1) Ia harus mengaku bahwa ia adalah seorang berdosa; 2) Ia harus mengaku tidak puas dengan pegangan yang lama dan telah melihat bahwa prinsip lama atau agama itu tidak mungkin memberikan kepuasan rohani; 3) Ia harus mulai berkeinginan untuk mengetahui tentang jalan yang harus ditempuh.

Kabar Baik harus disampaikan dengan jelas dan sederhana. Heath memberikan pedoman penyampaian kabar baik melalui empat fakta rohani. ${ }^{43}$ Pertama, saya telah berbuat dosa dan patut menerima hukuman maut yang kekal (Rm. 3: 23; 6: 23; Yes. 59: 2). Kedua, saya tidak sanggup melepaskan diri dari hukuman maut (Ef. 2: 8-9; Rm. 3: 30; Yoh. 14: 6). Ketiga, Yesus adalah satu-satunya jalan

\footnotetext{
${ }^{41}$ Heath, Penginjialn Dan Pelayanan Pribadi.

${ }^{42}$ Ibid.

${ }^{43}$ Ibid.
}

pelepasan bagi saya karena Ia telah menjadi pengganti saya untuk dihukum pada salib (Rm. 5: 8; 1 Pet. 2: 24; 1 Pet. 3: 18). Keempat, saya harus menerima Yesus secara pribadi untuk memperoleh keselamatan yang telah Ia sediakan (Yoh. 1: 12; Why. 3:20). Fakta-fakta Alkitab itu harus disampaikan dengan teratur, penuh kasih, dan dengan satu tantangan agar akal dari mahasiswa yang dilayani menguasai faktafakta itu, hatinya (emosinya) tertarik kepada Yesus, dan kehendaknya menyetujui Yesus sebagai dasar keselamatannya.

Kedua, bagi mahasiswa teologi yang telah menerima Yesus sebagai Tuhan dan Juru Selamat pribadi, baik itu petobat baru maupun orang percaya yang berproses untuk menjadi serupa dengan Yesus adalah dengan menggabungkannya dalam sebuah komunitas orang percaya. KTBK merupakan komunitas yang tepat bagi para petobat baru dan orang percaya dalam menuju kehidupan Kristen yang dewasa. Melalui KTBK mahasiswa teologi yang telah percaya Yesus ditolong untuk belajar firman Tuhan, lebih mengenal Yesus melalui doa dan penyembahan, memiliki persekutuan kasih dengan anggota yang lain, dan tergerak hati untuk bermultiplikasi. ${ }^{44}$

Kedewasaan penuh di dalam Yesus dan menjadi serupa dengan Yesus dapat terjadi jika setiap anggota memiliki komitmen untuk bertumbuh melalui KTBK. Di dalam komunitas KTBK, setiap anggota akan memiliki lingkungan yang tepat di mana antar anggota dapat saling menolong dalam kesulitan, saling mendo-

\footnotetext{
${ }^{44}$ Haryono and Yuliati, Pemuridan

Kontekstual: Contextual Bible Group.
} 
rong untuk taat kepada firman Tuhan, saling mengingatkan, saling menasihati, dan hal-hal saling membangun lainnya.

KTBK pada era New Normal pandemi Covid-19 mempunyai kelebihan di mana anggota KTBK yang terdiri dari 36 orang memungkinkan untuk melakukan pertemuan offline dengan menerapkan protokol kesehatan bagi anggota yang berasal dari daerah yang sama dan tempat tinggal yang berdekatan. Namun, jika lokasi antar anggota jauh, KTBK dapat dilakukan dengan memanfaatkan bantuan dari media TIK untuk melakukan pertemuan secara virtual, seperti whatsapp group call, zoom meeting, google meet, webex, dan aplikasi-aplikasi lainnya yang memberikan fasilitas video conference.

Penggunaan media sosial terbukti meningkatkan interaksi sosial. Semakin tinggi penggunaan media sosial, semakin tinggi pula interaksi sosial terjalin. ${ }^{45} \mathrm{Hal}$ ini terjadi karena tujuan utama diciptakan media sosial adalah untuk memungkinkan seseorang berkomunikasi dan berinteraksi dengan orang lain di seluruh dunia. Salah satu interaksi sosial yang ditingkatkan dengan penggunaan media sosial adalah kerja sama. Media sosial dapat meningkatkan interaksi antarorang atau sekelompok orang untuk mencapai tujuan yang sama. Berdasarkan hal tersebut, penggunaan media sosial dalam komunitas KTBK dapat meningkatkan interaksi antaranggota sehingga antaranggota KTBK dapat saling

\footnotetext{
${ }^{45}$ Sisrazeni, "Hubungan Penggunaan Media Sosial Dengan Interaksi Sosial Mahasiswa Jurusan Bimbingan Konseling Tahun 2016/2017 IAIN Batusangkar," 2nd International Seminar on Education 2017 Empowering Local Wisdom on Education for Global Issue Batusangkar, (2017): 12.
}

bekerja sama dan saling membangun dalam seluruh kehidupan untuk mencapai tujuan yang sama, yaitu kedewasaan penuh dan keserupaan dengan Yesus.

Ketiga, mahasiswa perlu diperlengkapi dengan keterampilan melayani (Train to Minister). Pada tahap ini, pelayan mendorong para mahasiswa untuk memberitakan Kabar Baik dan memuridkan dengan cara memberikan teladan. Teladan dapat diberikan setiap waktu dan setiap saat menggunakan media-media komunikasi. Pelatihan terbaik untuk melayani adalah dengan memberikan teladan dalam pelayanan, sikap yang ditunjukkan, cara hidup, cara berbicara, pendekatan-pendekatan penyampaian Kabar Baik, dan hal-hal lainnya.

Mahasiswa teologi yang telah menunjukkan pertumbuhan dilibatkan dalam pelayanan, didorong untuk memberitakan Kabar Baik dan memuridkan. Hal ini dimaksudkan agar para mahasiswa teologi benar-benar siap menghadapi segala tantangan yang muncul dalam proses melayani. Dalam pelayanan yang dilakukan oleh para mahasiswa, dosen bertugas untuk mengawasi perkembangan dan menolong para mahasiswa jika mengalami kesulitan. Pengawasan dilakukan untuk melihat sejauh mana mereka telah melayani dengan langkah-langkah yang tepat. Pengawasan juga bertujuan agar para mahasiswa memiliki tanggung jawab dalam melakukan pelayanan.

$$
\text { Keempat, mengutus para }
$$

mahasiswa untuk bermultiplikasi (Release to Be a Disciple Maker). Para anggota yang telah diperlengkapi dan siap untuk memuridkan, diutus dengan pengurapan Roh Kudus. Para pemimpin dapat mendoakan dan atau dengan penumpangan 
tangan, memohonkan supaya Roh Kudus terus menyertai dan membuat berhasil dalam pelayanan para anggota. Meskipun para anggota sudah memuridkan, tetapi relasi dengan pemimpinnya tetap harus terjaga supaya tetap dapat mengalami pertumbuhan.

\section{KESIMPULAN DAN SARAN}

Strategi pemuridan mahasiswa di sekolah tinggi teologi pada era New Normal pandemi Covid-19 memiliki tujuan untuk memberitakan kabar baik dan memuridkan para mahasiswa yang belum dan telah menerima Yesus sebagai Tuhan dan Juru Selamat pribadi. Strategi ini dapat menjadi solusi yang tepat, alkitabiah, dan kontekstual dalam pelayanan mahasiswa pada masa pandemi Covid-19 untuk menghasilkan para petobat baru dan menjadikan para mahasiswa yang dewasa penuh dan serupa dengan Yesus.

Saran penulis dalam penelitian ini adalah diperlukan kreativitas pada penggunaan media TIK dalam pelayanan mahasiswa sehingga media TIK dapat dimanfaatkan dengan semaksimal mungkin. Selain itu, perlu dilakukan penelitian lanjutan untuk mengetahui efektivitas strategi pelayanan mahasiswa pada masa pandemi Covid-19 ini.

\section{REFERENSI}

Dempsey, Rod. "What Is God's Will for My Life? Disciple!” In Innovate Church. Nashville: B \& H Academic, 2008.

Dewi, Retia Kartika. "100 Dokter Meninggal Karena Covid-19, Apa Penyebabnya?" Kompas. Com . Last modified 2020. Accessed September 2, 2020 . https://www.kompas.com/tren/read/20

20/08/31/191500565/100-dokter-

meninggal-karena-covid-19-apa-

penyebabnya-?page $=$ all .

Haryono, Timotius, and Daniel Fajar

Panuntun. "ANDIL PEMURIDAN

KONTEKSTUAL YESUS KEPADA

PETRUS YAKOBUS DAN

YOHANES TERHADAP

KETERBUKAAN KONSELING

MAHASISWA PADA MASA KINI."

Jurnal Gamaliel : Teologi Praktika

(2019).

Haryono, Timotius, and Trifena Yuliati.

Pemuridan Kontekstual: Contextual

Bible Group. Surakarta: Yayasan

Gamaliel, 2018.

Heath, Stanley. Penginjialn Dan

Pelayanan Pribadi. Surabaya:

YAKIN, 1979.

Hull, BIll. Choose The Life. Surabaya:

Literatur Perkantas Jawa Timur, 2004.

_. Panduan Lengkap Pemuridan.

Yogyakarta: Yayasan Gloria, 2014.

Kamil, Irfan. "UPDATE 1 September:

Kasus Suspek Covid-19 Tembus

80.675 Orang." Kompas. Com. Last

modified 2020. Accessed September

2, 2020.

https://nasional.kompas.com/read/202

0/09/01/15282601/update-1-

september-kasus-suspek-covid-19-

tembus-80675-orang.

Kemendikbud RI, Badan Pengembangan

dan Pembinaan Bahasa. "Hasil

Pencarian - KBBI Daring." Badan

Pengembangan Dan Pembinaan

Bahasa, Kementerian Pendidikan

Dan Kebudayaan Republik Indonesia, 2020.

Kementerian kesehatan Republik Indonesia. "Pedoman Pencegahan 
Dan Pengendalian COVID-19."

Pedoman kesiapan menghadapi COVID-19 (2020): 0-115.

Lumintang, Stevri Indra, and Danik Astuti Lumintang. Theologia Penelitian Dan Penelitian Theologis. Geneva Insani Indonesia, 2016.

Mendikbud. "SE Menteri Nomor 4 Tahun 2020." Jakarta: Kemendikbud, 2020.

Mona, Nailul. "Konsep Isolasi Dalam Jaringan Sosial Untuk Meminimalisasi Efek Contagious ( Kasus Penyebaran Virus Corona Di Indonesia)." Jurnal Sosial Humaniora Terapan 2, no. 2 (2020): 117-125.

Panuntun, Daniel Fajar, and Eunike Paramita. "Hubungan Pembelajaran Alkitab Terhadap Nilai-Nilai ( Kelompok Tumbuh Bersama Kontekstual )." Gamaliel : Teologi praktika 1, no. 2 (2019): 104-115.

Pratiwi, E W. "Dampak Covid-19 Terhadap Kegiatan Pembelajaran Online Di Sebuah Perguruan Tinggi Kristen Di Indonesia." Perspektif Ilmu Pendidikan 34, no. 1 (2020): 18.

Purba, Asmat. "Pemuridan Sebagai Tugas Dosen Pendidikan Agama Kristen Di Perguruan Tinggi." TEDC 8, no. 1 (2014): 68-73.

Putman, Jim, Bobby Harrington, and Robert E Coleman. DiscipleShift: Five Steps That Help Your Church to Make Disciples Who Make Disciples. Exponential Series. California:
Zondervan, 2013.

Sarumaha, Nurnilam, and Novie Deisy Pasuhuk. "Strategi Membangun Karakter Peduli Sesama Di Kalangan Mahasiswa Teologi Berdasarkan Filipi 2 : 1-8." Teruna Bhakti 2, no. 2 (2020): 133-145.

Setiadi, Ahmad. "Pemanfaatan Media Sosial Untuk Efektifitas

Komunikasi." Jurnal Humaniora 16, no. 2 (2016): 1-7.

Shipman, Michael. Amanat Agung Asli Rahasia Memuridkan Dunia Kini. Rahayu Group, 2014.

Sisrazeni. "Hubungan Penggunaan Media Sosial Dengan Interaksi Sosial Mahasiswa Jurusan Bimbingan Konseling Tahun 2016/2017 IAIN Batusangkar." 2nd International Seminar on Education 2017 Empowering Local Wisdom on Education for Global Issue Batusangkar, (2017): 12.

Syah, Rizqon H. "Dampak Covid-19 Pada Pendidikan Di Indonesia: Sekolah, Keterampilan, Dan Proses Pembelajaran." SALAM: Jurnal Sosial dan Budaya Syar-i 7, no. 5 (2020). Tomatala, Y. Penginjilan Masa Kini 1.

Malang: Gandum Mas, 1998.

Wagiran. Metodologi Penelitian

Pendidikan: Teori Dan Implementasi.

1st ed. Yogyakarta: Deepublish, 2015.

World Health Organization. "Q\&A on Coronaviruses (COVID-19).” Who, 2020. 